\title{
Optimalizace 3D modelů pro virtuální realitu
}

\author{
Miroslav Bednář ${ }^{1}$, David Krákora ${ }^{1}$, Michal Šimon ${ }^{1}$ \\ 1 Západočeská univerzita v Plzni, Fakulta strojní, Katedra průmyslového inženýrství a \\ managementu \\ Univerzitní 8, 306 14, Plzeň, Česká republika \\ bednarm@kpv.zcu.cz \\ krakorad@kpv.zcu.cz \\ simon@kpv.zcu.cz
}

\begin{abstract}
Anotace: Článek se zabývá analýzou 3D modelů vytvářených v různých CAD softwarech, které se hojně využivají napříč celým průmyslem a jejich implementací do virtuální reality. Tyto modely jsou velice náročné pro výpočet $v$ softwarech používaných pro virtuální realitu. $Z$ tohoto důvodu bylo potřebné zjistit, jaký program a jaké nastavení exportů je nejvhodnější pro implementaci do VR.
\end{abstract}

\section{1 Úvod}

Hlavním tématem tohoto článku je Optimalizace 3D modelů pro virtuální realitu. Obecně Ize 3D modely rozdělit do dvou základních skupin: modely vytvořené $C A D$ softwary a modely vytvořené pomocí alternativních modelovacích softwarů. První skupina se vyznačuje velkou náročností na tvorbu, jelikož v sobě musí obsahovat veškeré součástky, které v sobě reálný model má. Tyto modely jsou pro virtuální realitu takřka nepoužitelné, jelikož jejich složitost je pro vykreslování v programech pro tvorbu a úpravu aplikací do VR vysoce náročná. Aplikace totiž vykreslují veškeré součástky, které $\checkmark$ sobě daný model má, a to i přesto, že tyto součástky nejsou skrze různé pláště a kryty vidět. Druhou skupinu tvoří modely tvořené $v$ alternativních programech pro modelování, jako je například Blender, SketchUp, 3Ds Max, či Maya. $V$ těchto programech se modely tvoří jiným způsobem, a to zejména tak, že je tvořen pouze viditelný obsah, nikoliv funkční prvky daného modelu. Tyto modely jsou tak přizpůsobené $\mathrm{k}$ dalšímu použití a úpravám, díky kterým Ize tyto modely (zejména díky jejich jednoduchosti) implementovat do aplikací pro virtuální realitu. Většina těchto programů disponuje možností úprav základních vlastností modelů, jako je vzhled, funkčnost a pohyblivost. Mezi tyto základní úpravy patří například texturování, animování, renderování, atd.

Cílem tohoto výzkumu bylo tedy zoptimalizovat postup při převodu 3D modelů z CAD softwarů do programů zabývajících se tvorbou aplikací pro virtuální realitu. Hlavním důvodem je využívání průmyslových modelů pro virtuální návodky, které slouží především kzjednodušení procesu zaškolování zaměstnanců. Díky tomu není potřeba zastavovat linku pro zaškolení nových zaměstnanců, ale vše je možné provádět přímo ve VR. Další využití těchto modelů ve virtuální realitě může být př̆i navrhování pracovišt', kdy se celé 
pracoviště navrhuje ve 3D. Toto pracoviště se poté převádí do virtuální reality a následně je možné jej upravovat dle nedostatků zjištěných přímo ve vytvořené aplikaci. Díky tomu není potřeba zastavovat výrobní halu novými pracovišti a poté je postupně upravovat, ale tento celý proces může být uskutečňován prímo ve VR. Další výhodou tvorby pracoviště ve VR je možnost optimalizace tohoto pracoviště na základě ergonomické analýzy, kterou Ize rovněž provádět prímo $v$ aplikacích na virtuální realitu, a to především díky spojení brýlí na virtuální realitu a senzorů z různých obleků, které Ize automaticky propojit právě s těmito aplikacemi.

\section{CAD softwary}

Tato kapitola popisuje nejpoužívanější CAD softwary a jejich možnosti pro import a export 3D modelů. Slouží jako základ pro pochopení modelování $v$ těchto softwarech a také pro pochopení základů převodů formátů.

Co je vlastně CAD? Z anglického „computer-aided design“ se do češtiny překládá jako počítačem podporované projektování. Jde o velkou oblast IT, která zastřešuje širokou činnost navrhování. Jednoduše Ize říct, že se jedná o používání pokročilých grafických programů pro projektování, místo rýsovacího prkna. CAD aplikace vždy obsahují grafické, geometrické, matematické a inženýrské nástroje pro kreslení plošných výkresů a modelování objektů a dějů reálného světa. Pokročilejší reší výpočty, analýzy a řízení systémů (výroby, zařízení). Blízkým příbuzným je také oblast počítačových vizualizací, protože virtuální 3D návrhy jsou často klientům prezentovány ve formě fotorealistických vizualizací. [1]

Rozdělení:

- obecné CAD systémy

$\circ 2 \mathrm{D}$

-3D

- objemové

- povrchové

- specializované CAD systémy

- strojírenství - CAM (computer-aided

manufacturing), CAE (computer-aided engineering)

- stavebnictví a architektura - AEC (Architecture-Engineering-

Construction), BIM (Building Information

Model), CAAD (Computer-aided architectural design)

- potrubní systémy a technické zařízení budov

- liniové a dopravní stavby

- správa nemovitostí - FM (Facility Management)

- elektrotechnika - PCB (Printed Circuit Boards), EDA (Electronic design automation)

- územní plánování a geografie - GIS (Geographic Information

Systems) [2] 
Mezi nejznámější CAD softwary patří:

- Autodesk Inventor

- SolidWorks

- Catia

- NX

- Fusion 360

- AutoCAD

- CorelCAD

- Solid Edge

Pro výzkum složitosti exportovaného 3D modelu byly zvoleny programy: Autodesk Inventor 2019, Catia V5R20, SolidWorks 20/21 a NX12, jelikož jsou to programy, se kterými se nejčastěji setkáme $v$ průmyslových podnicích.

\section{Optimalizace 3D modelů}

Další částí tohoto článku popisuje již samotnou optimalizace 3D modelů, kdy bylo potřeba vyzkoumat složitost modelů vytvářených různými CAD programy pro programy, které se zabývají tvorbou aplikací do VR. Tato složitost se zjišt'uje dle počtu polygonů, které jsou základem pro výpočet vizuální stránky modelu. Dle počtu polygonů Ize vytvářet různě kvalitní 3D modely. Modely, které mají málo polygonů jsou tzv. low-poly a nejsou moc kvalitní. Tyto modely jsou však velice přívětivé pro tvorbu aplikací do VR. Nejsou př́liš náročné na výpočet a není proto potřebná výkonná výpočetní soustava, ale stačí počítač, či třeba mobilní telefon. Naopak high-poly modely, které mají velké množství polygonů jsou vysoce kvalitní a odráží se to $v$ potřebném výkonu zařízení, které tyto modely přehrává. Pro filmařinu jsou tyto modely základním kamenem a je proto potřebný vysoce výkonný počítač, či výpočetní stanice, která dokáže převézt takto kvalitní modely s pomocí renderování do filmu.

Samotný výzkum zabývající se počtem polygonů daných vymodelovaných částí se zaměřuje na konstrukční CAD programy, které jsou základem každého konstruktéra. Tyto programy však nejsou přiliš př́ivětivé pro převod do aplikací, které se používají napríklad pro virtuální 2D a 3D návodky, či prímo pro aplikace vytvářené ve virtuální realitě. Právě proto je potřeba vyzkoumat složitost modelů, které se vytváří v různých CAD programech.

Pro výzkum byly zvoleny základní CAD programy, se kterými se setkáme $v$ různých společnostech. $V$ těchto programech byl vytvořen stejný model o stejných rozměrech. Poté byl daný model vyexportován do jednotného formátu, který je možné naimportovat do aplikace Blender, která se využívá právě pro tvorbu $3 \mathrm{D}$ modelů a ve které je možné zjistit složitost modelu právě $\mathrm{z}$ hlediska polygonů. 
Postup tohoto výzkumu byl tedy následující:

1. Vytvoření jednotného modelu o stejných rozměrech $v$ různých CAD programech

2. Export modelů na .stl, popřípadě .obj (u některých programů je možná volba kvality modelu - u této možnosti byly zvoleny všechny varianty)

3. Import modelů do aplikace Blender a zjištění počtu polygonů

4. Porovnání velikostí vyexportovaných souborů

Při tvorbě modelu ve zmíněných programech byl velký důraz kladen na tvorbě zaoblených ploch, které bývají při exportu nejnáročnější a obsahují nejvíce polygonů, jelikož tyto programy používají pro výpočet těchto ploch jiný algoritmus, než programy pro tvorbu aplikací a je tedy jednodušší tyto modely prevést do 3D podoby.

Na následujícím obrázku je 3D model, který byl zvolen jako výchozí:

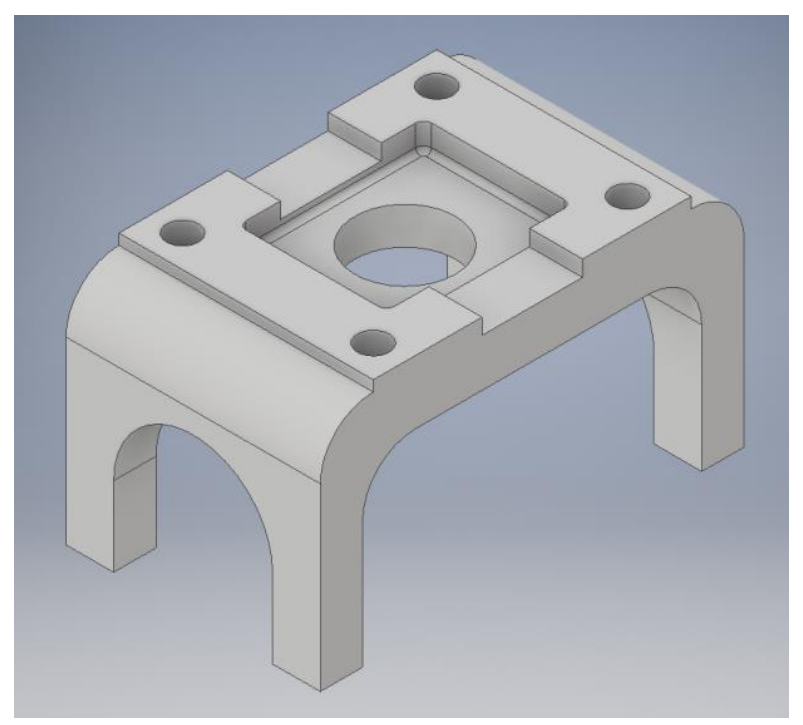

Obrázek 1 - 3D model pro výzkum

Tento model o stejných rozměrech byl vytvořen ve všech zvolených CAD programech. Model byl sestaven ze stejného materiálu, avšak vizualizace se $v$ různých programech liší. Porovnání vizualizace těchto modelů $v$ těchto programech je na následujících obrázcích: 


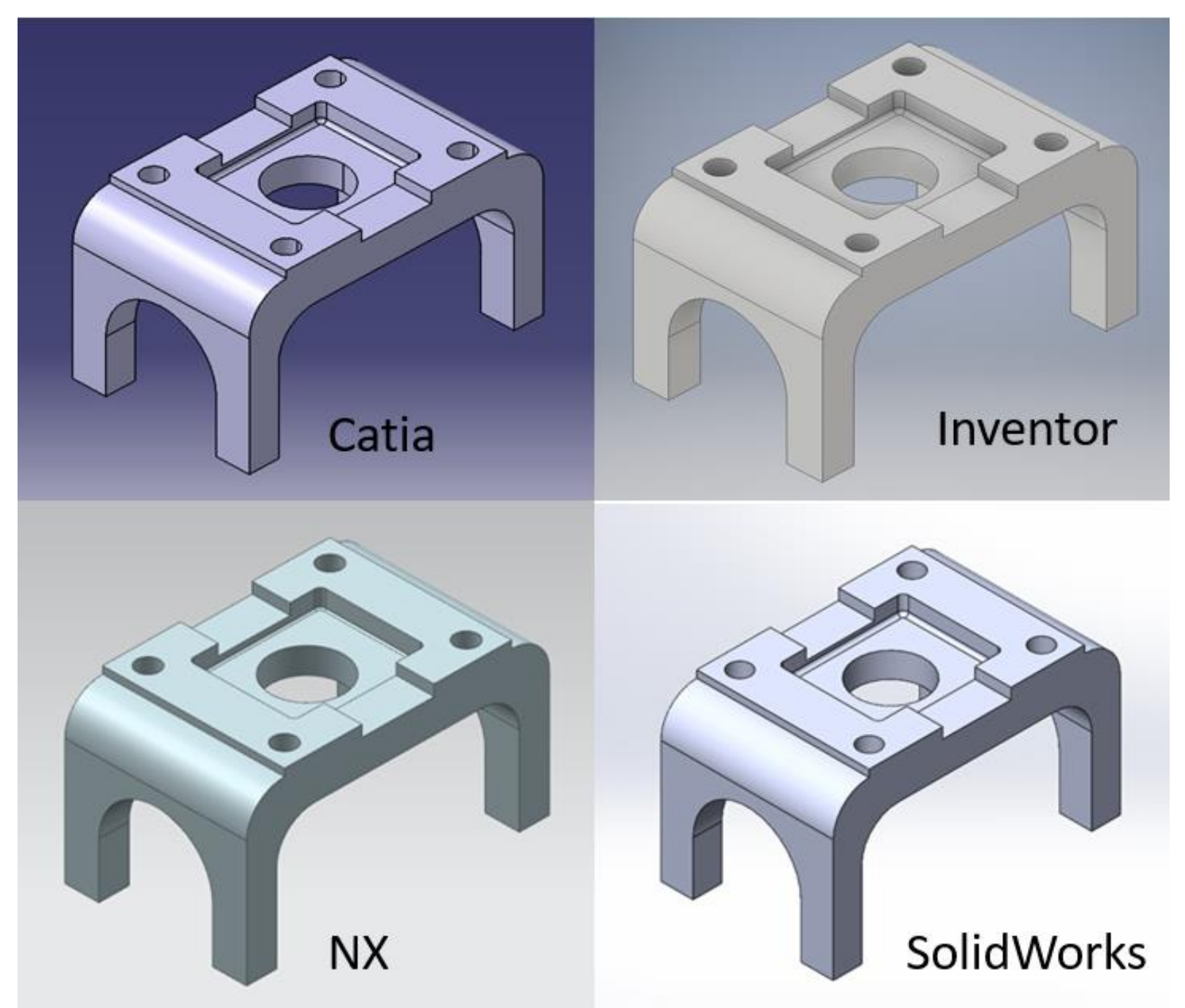

Obrázek 2 - Všechny CAD modely

Tyto modely byly exportovány do formátu, který podporuje Blender. Po exportu bylo již možné zjistit velikost daného modelu. Tyto velikosti jsou základem pro zjištění složitosti modelu, avšak nejsou dostatečně vypovídající o složitosti z hlediska počtu polygonů.

Tabulka 1 - Porovnání velikostí modelů

\begin{tabular}{|l|r|}
\hline \multicolumn{1}{|c|}{ CAD } & Velikost \\
\hline Catia & $315 \mathrm{kB}$ \\
\hline Inventor & $234 \mathrm{kB}$ \\
\hline NX & $346 \mathrm{kB}$ \\
\hline SolidWorks & $183 \mathrm{kB}$ \\
\hline
\end{tabular}


Z tabulky výše je patrné, že největší model vytváří program NX, naopak nejmenší je z programu SolidWorks. Jak již bylo ale zmíněno, velikost nemusí vypovídat o složitosti 3D modelu, ale je jedním ze základních parametrů pro volbu vhodného programu pro tvorbu těchto modelu.

Po exportu modelů do formátu .stl a zjištění jejich velikostí bylo potřeba tyto modely naimportovat do programu Blender. Zde měli tyto modely různou vizualizaci, která se odlišuje především díky počtu polygonů, které vykreslují daný model.

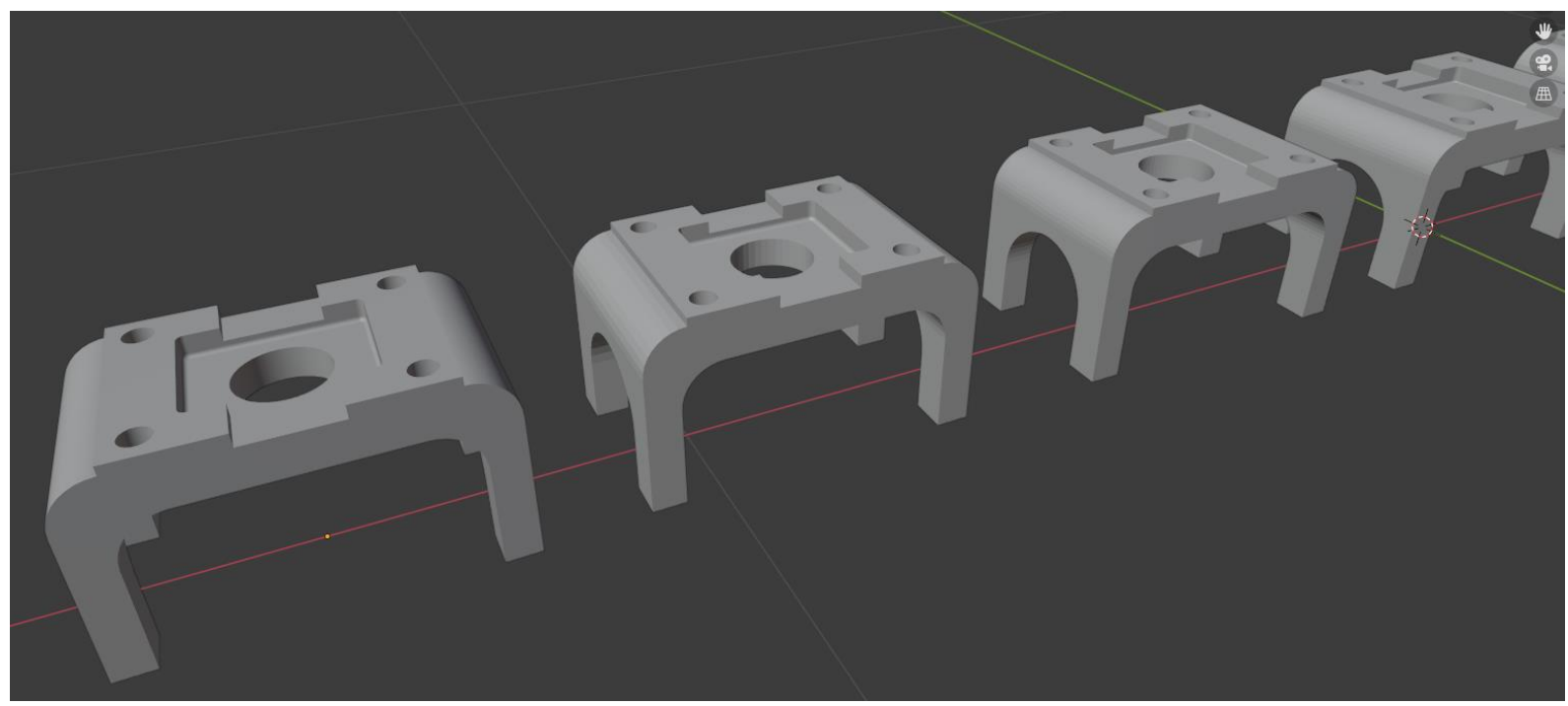

Obrázek 3 - Vykreslení modelů v Blenderu

Na obrázku výše je poznat rozdíl ve vykreslení modelů v Blenderu, kdy některé modely nevypadali zaobleně, což způsobuje právě menší počet polygonů.

\section{Výsledek}

Jak již bylo zmíněno, nejdůležitější částí pro výzkum bylo zjištění počtu polygonů (triangles), bodů (vertices) a hran (edges) každého z modelů, jelikož právě tyto hodnoty vypovídají o tom, zdali je 3D model možno implementovat do aplikace pro virtuální realitu. Porovnání těchto modelů z hlediska těchto parametrů je na následující tabulce. 
Tabulka 2 - Porovnání vlastností modelů

\begin{tabular}{|l|r|r|r|}
\hline \multicolumn{1}{|c|}{ CAD } & \multicolumn{1}{c|}{ Vertices } & \multicolumn{1}{c|}{ Edges } & \multicolumn{1}{c|}{ Triangles } \\
\hline Catia & 541 & 1647 & 1098 \\
\hline Inventor - Low & 594 & 1806 & 1204 \\
\hline Inventor - High & 2498 & 7518 & 5012 \\
\hline NX & 993 & 3003 & 2002 \\
\hline SolidWorks - Low & 428 & 1308 & 872 \\
\hline SolidWorks - High & 1117 & 3375 & 2250 \\
\hline
\end{tabular}

$Z$ této tabulky Ize vidět, že nejvýhodnější pro tvorbu 3D modelů vhodných pro implementaci do aplikacích určených pro průmysl, jako jsou 2D, 3D a VR návodky je program SolidWorks, který se svou Low verzí modelu má hodnotu 872 polygonů. Pro využívání programu SolidWorks bylo zjištěno, že tento program je možné pořídit ve 3 komerčních a 3 výukových verzích a zkušební licence tohoto CAD programu je na 2 týdny. Dalším vhodným programem je Catia, která je ovšem poněkud složitější a je vhodná spíše pro konstruktéry než pro začátečníky, kteři chtějí modelovat v CAD programech. Pro ty je spíše vhodný program Inventor, který je možné jako student získat zdarma.

Při volbě nejvhodnějšího CAD programu bylo ovšem potřeba také uvažovat o možnostech exportu $v$ různých formátech, jelikož každý formát se převede do dalšího programu jinak, a tudíž i jeho vizuální stránka může být jiná. Po několika pokusech bylo zjištěno, že nejvhodnějším formátem pro export $3 \mathrm{D}$ modelů z CAD programů je formát .obj, který dokáže jednoduše vykreslit zaoblenou hranu s menším množstvím polygonů. $Z$ toho důvodu bylo potřeba zvolit kompromis, mezi programem, který vytvoří model s nejmenším počtem polygonů a programem, který dokáže vyexportovat formát .obj. Jelikož toto nezvládá ani jeden ze softwarů Catia a SolidWorks, byl jako nejvýhodnější CAD program pro tvorbu 3D modelů pro aplikace upravující modely pro virtuální realitu zvolen program Autodesk Inventor. [3] 

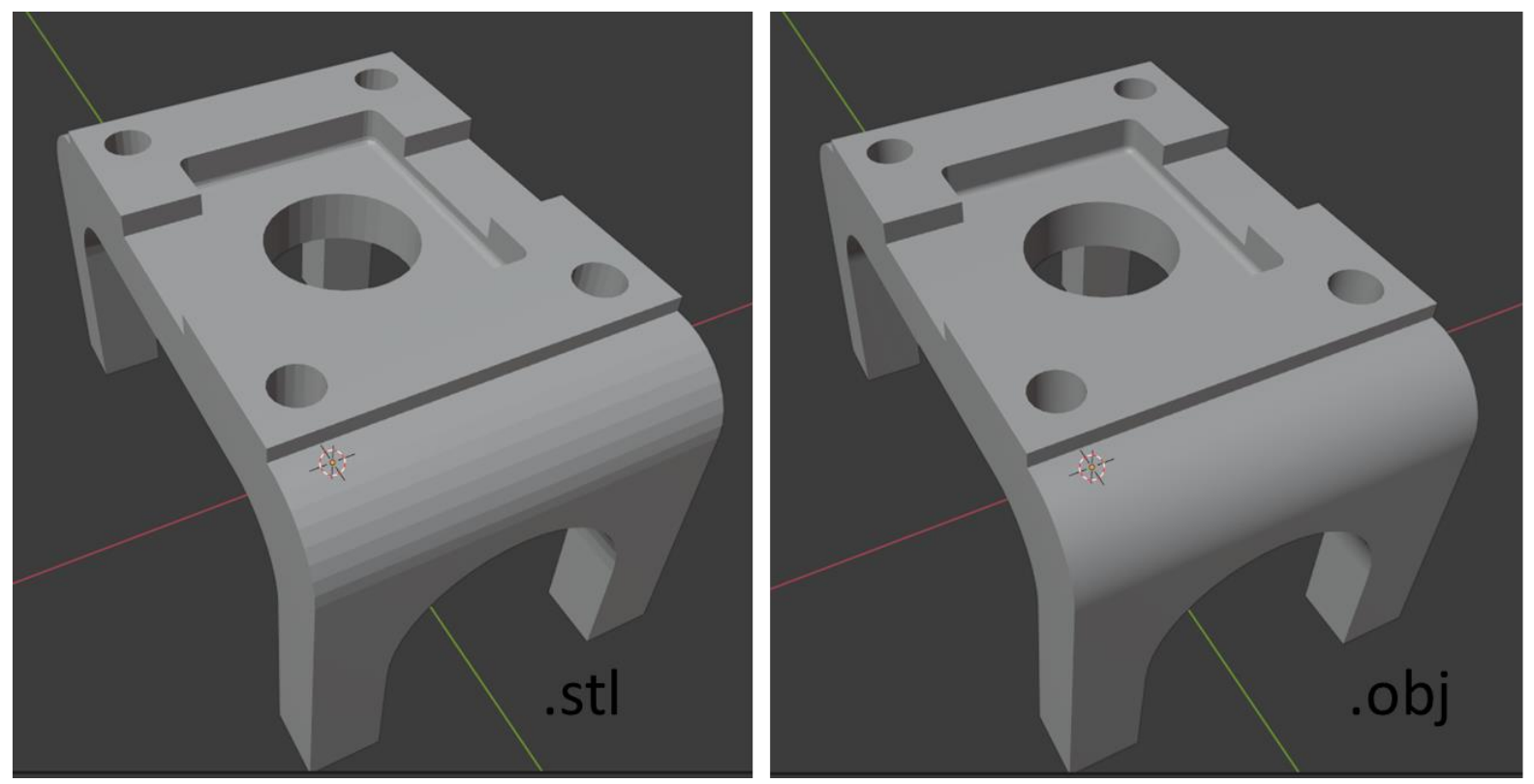

Obrázek 4 - Rozdíly mezi formáty

\section{Závěr}

Tento článek analyzoval složitost $3 D$ modelů vytvářených v různých $C A D$ softwarech vyexportovaných pro programy tvořící modely pro virtuální realitu. Při analýze byly zjištěny různosti v počtu polygonů prí exportu z různých $C A D$ softwarů. Z tohoto hlediska vyšel jako nejvhodnější program pro tvorbu $3 D$ modelů do aplikací ve virtuální realitě program SolidWorks, který při nastavení low quality modelu měl pouhých 872 polygonů. Jelikož však tento model ve formátu .stl nedokázal dobře vykreslit zaoblené hrany, bylo potřeba nalézt optimální řešení pro tvorbu $3 D$ modelů $v C A D$, které by mělo kvalitnější vizuální stránku. $Z$ toho důvodu bylo vyexportováno několik dalších formátů, které jsou kompatibilní s programy pro tvorbu aplikací do VR. Jako nejvhodnější se jevil formát .obj, který Ize importovat do spousty dalších programů. Tento formát dokáže vyexportovat program Autodesk Inventor, který při exportu vytvořeného modelu při nižším nastavení kvality modelu vykazoval 1204 polygonů. Inventor byl tedy zvolen jako optimální CAD software pro tvorbu 3D modelů a to zejména $z$ hlediska poměru počet polygonů vs. kvalita vykreslování v modelovacích programech pro VR.

\section{Poděkování}

Tento článek byl vytvořen za podpory interního grantu Západočeské univerzity v PIzni číslo SGS-2021-028 s názvem Vývojové a tréninkové prostředky pro interakci člověka a kyber-fyzického výrobního systému. 


\section{Použité zdroje}

[1] Procore Technologies, Inc. What is Computer-Aided Design (CAD) and Why It's Important. [Online] [Citace 16. 9. 2021.]

https://www.procore.com/jobsite/what-is-computer-aided-design-cad-and-why-itsimportant/

[2] CADBIM.CZ - CADBIM WiKI - CAD. CAD. [Online] [Citace 16. 9. 2021.]

[3] technology-support, trvalá podpora vašich provozů. CAD, standardy, rozdělení, možnosti, formáty sdílení dat, překladače. [Online] [Citace 17. 9. 2021.] 